\title{
Perkembangan Karir Terhadap Kepuasan Kerja Penyuluh Perikanan di Badan Ketahanan Pangan Pelaksana Penyuluhan Pertanian Perikanan dan Kehutanan Kabupaten Bogor
}

\author{
[Career Development Against Job Satisfaction of Fisheries Extension Workers \\ At the Food Security Agency Implementing Agricultural Extension of Fisheries and Forestry \\ Bogor Regency] \\ Sobariah \\ Sekolah Tinggi Perikanan, Jurusan Penyuluhan Perikanan \\ Jalan Cikaret Nomor 1 Bogor 16001, Jawa Barat \\ Diterima: 06 Maret 2015; Disetujui: 13 Juni 2015
}

\begin{abstract}
Abstrak
Upaya meningkatkan kepuasan kerja penyuluh perikanan banyak factor yang perlu mendapat perhatian, yaitu pengembangan karier dari penyuluh tersebut. pengembangan karir dapat meningkatkan kepuasan kerja bagi penyuluh perikanan sebagai tenaga fungsuional dibidangnya. sehingga berdampak positif dalam lingkungan ekternal instansi tersebut yakni peningkatan kepercayaan masyarakat dalam pemberian penyuluhan dan transfer teknologi bidang pertanian umumnya dan perikanan khususnya.berdasarkan hal tersebut, dilakukan penelitian tentang pengembangan karir dan kepuasan kerja penyuluh. adapun tujuan penelitian adalah untuk mengetahui sejauhmana pengaruh pengembangan karir terhadap kepuasan kerja penyuluh perikanan di badan ketahanan pangan pelaksana penyuluhan perikanan dan kehutanann kabupaten bogor, dengan menggunakan metode deskriptif eksploratif. berdasarkan penelitian yang dilakukan mengenai pengaruh pengembangan karier terhadap kepuasan kerja di badan ketahanan pangan pelaksana penyuluhan perikanan dan kehutanann terhadap 51 orang penyuluh perikanan dari 209 orang pegawai dan hasil pengolahan data terhadap variabel bebas pengembangan karier (x) serta variabel terikat kepuasan kerja (y) badan ketahanan pangan pelaksana penyuluhan perikanan dan kehutanann diperoleh data hitung yang dapat diambil beberapa kesimpulan sebagai berikut: 1. hasil uji t variabel pengembangan karier (x) terhadap kepuasan kerja (y) pada badan ketahanan pangan pelaksana penyuluhan perikanan dan kehutanann menunjukkan bahwa nilai thitung sebesar 8,407 dan $\mathrm{t}_{\text {tabel }}$ sebesar 1,,588 pada level significants 0,05 dan probabilitas 0,000 . hal ini berarti $t_{\text {hitung }}=8,407>t_{\text {tabel }}=1,588$, maka ho ditolak dan ha diterima, berarti terdapat pengaruh pengembangan karier ( $\mathrm{x}$ ) terhadap kepuasan kerja (y) pada badan ketahanan pangan pelaksana penyuluhan perikanan dan kehutanann kabupaten bogor. koefisien korelasi pengembangan karier (x) secara bersama-sama terhadap kepuasan kerja (y) pada badan ketahanan pangan pelaksana penyuluhan perikanan dan kehutanann adalah 0,876 sehingga diperoleh nilai koefisien determinasi sebesar 0,,876 atau 87,6\%. hal ini berarti bahwa faktor-faktor lain di luar yang tidak diteliti namun berpengaruh juga adalah sebesar 12,4\%.
\end{abstract}

Kata kunci : kerja, motivasi, pendidikan

\begin{abstract}
Efforts to improve job satisfaction yak fishing instructor tire factor that needs to be attention, thecareerdevelopment of the extension. career developmentcan increase job satisfaction for fisheries extension as power fungsuionain the field. so that the positive impact on the external environment of the institutionincrease public confidence in the extension services and technology transferagriculture in general and fisheries in particular. based on that, doresearch on career development and job satisfaction of extension. the purposethe study is to determine the extent of the influence of career developmentjob satisfaction turtle $\sim \mathrm{h}$ fisheries in badan ketahanan pangan pelaksana penyuluhan perikanan dan
\end{abstract}


kehutanannbogor, usingexplorative descriptive method. based on research done on the effect ofcareerdevelopment on job satisfaction in badan ketahanan pangan pelaksana penyuluhan perikanan dan kehutanann against 51 extensionfishery of $209 \mathrm{employees}$ and the data processing of the independent variablescareer development (x) andthedependent variable job satisfaction (y) data obtained badan ketahanan pangan pelaksana penyuluhan perikanan dan kehutananncount that can be drawnsome conclusions as follows: 1 . the results of the $\mathrm{t}$ test variablecareer development $(\mathrm{x})$ on job satisfaction $(\mathrm{y})$ on badan ketahanan pangan pelaksana penyuluhan perikanan dan kehutanann shows thattcount at 8.407 and ttable of 1,588 at the 0.05 level andthe probability significants0,000. this means $t=$ $8.407>$ table $=1.588$, then ho is rejecte andha accepted, meaningthere are significant career development $(\mathrm{x})$ on job satisfaction (y) on kp5kbogor regency. the correlation coefficient career development (x) togetheron job satisfaction (y) on badan ketahanan pangan pelaksana penyuluhan perikanan dan kehutanann is 0.876 thus obtained coefficient determination by 0,876 or $7.6 \%$.his means that other factors outside thenot examined but is also influenced by $12.4 \%$.

Keywords: career development, job satisfaction

\section{Pendahuluan}

Latar Belakang

Profesionalisme aparatur pemerintah yaitu PNS harus diitingkatkan kualitasnya baik dari segi pengetahuan (intelektual), keahlian (managerial), keterampilan (skill) dan tata sikap (behaviour) secara terencana, terarah, berkesinambungan melalui upaya pengembangan potensi, karier dan kesejahteraan, Mariot TE.Hariandja,( 2002;)

Dengan kejelasan pola karier pegawai negeri sipil tersebut, maka manfaat ganda akan diperoleh baik bagi instansi/lembaga, antara lain memungkinkan akan terlaksananya fungsi dan tercapainya tujuan secara efektif dan efisien, begitupun bagi personal pegawai negeri sipil seperti adanya kepastian arah pengembangan dan pemberdayaan pegawai (Empowering Employeer) serta menghindarkan perilaku tidak adil dan subyektivitas dalam proses manajemen kepegawaian, Danang Sunyoto(2012,) Dengan demikian pegawai negeri sipil memiliki kesempatan yang sama dalam meniti jenjang karir mulai dari pangkat atau jabatan terendah hingga yang tertinggi sesuai dengan kompetensi yang dimilikinya.

\footnotetext{
$\triangle$ Penulis korespondensi

Alamat surel: sobariahana@yahoo.com
}

Badan Ketahanan Pangan Pelaksana Penyuluhan Pertanian Perikanan dan Kehutanan sebagai salah satu lembaga teknis daerah yang mempunyai fungsi mentransfer teknologi dibidang pertanian, perikanan kepada petani, pembudidaya atau masyarakat merupakan satuan administras pangkal penyuluh pertanian, perikanan. Kinerja penyuluh sebagai ujung tombak pembangunan perikanan sangat dipengaruhi oleh berbagai faktor diantaranya adalah kepuasan kerja.Kepuasan Kerja.

Seorang karyawan akan merasa nyaman dan tinggi loyalitasnya padaperusahaan apabila memperoleh kepuasan kerja sesuai dengan apa yangdiinginkan. Menurut Dole and Schroeder (2001), kepuasan kerja dapatdidefinisikan sebagai perasaan dan reaksi individu terhadap lingkunganpekerjaannya, sedangkan Testa (1999) mendefinisikan kepuasan kerja merupakan kegembiraan atau pernyataan emosi yang positif hasil dari penilaian salah satu pekerjaan atau pengalaman-pengalaman pekerjaan.

Locke (dalam Testa, 1999) juga menjelaskan bahwa bahwa kepuasan kerja mencerminkan kegembiraan atausikap emosi positif yang berasal dari pengalaman kerja seseorang. Kegembiraanyang dirasakan oleh 
karyawan akan memberikan dampak sikap yang positif bagikaryawan.dan status sosial yang ditingkatkan. Oleh karena itu, individu-individu yangmempersepsikan bahwa keputusan promosi dibuat secara adil, kemungkinanbesar karyawan akan mengalami kepuasan dalam pekerjaannya. Sehubungan denga kepuasan kerja tidak lepas juga dengan motivasi dimana motivasi adalah kemauan untuk memberikan upaya lebih untuk meraih tujuan organisasi, yang disebabkan oleh kemauan untuk memuaskan kebutuhan individual (Robbins, 1996). Lebih lanjut Luthans (1995), secara spesifik "sikap loyalitas" karyawan ini diindikasikan dengan tiga hal, yaitu (1) einginan kuat seseorang untuk tetap menjadi anggota organisasinya, (2) kemauan untuk mengerahkan usaha untuk organisasinya, dan (3) keyakinan dan penerimaan terhadap nilai-nilai dan tujuan organisasi.

Dalam upaya pengembangkan karier pegawai fungsional pada Badan Pelaksana Penyuluhan Pertanian Perikanan dan Kehutanan, terdapat berbagai faktor yang perlu mendapat perhatian, antara lain pengembangan karier pegawai agar dapat meningkat. Sehingga kepuasan kerja yang dirasakan para pegawai dalam melaksanakan pekerjaannya juga akan dapat meningkat.

Danang sunyoto (2012) pengembangan karier dari para pegawai di instansi tersebut akan meningkatkan kepuasan kerja sehingga berdampak positif dalam lingkungan eksternal instansi yakni peningkatan kepercayaan masyarakat dalam memberikan penyuluhan maupun transfer teknologi di bidang pertanian secara umum. Berdasarkan latar belakang tersebut maka dilakukan penelitian mengenai pengembangan karier, dan kepuasan kerja penyuluh.

\section{Rumusan Masalah}

Berangkat dari paparan di atas dan untuk lebih memfokuskan masalah yang digali, maka masalah yang dibahas dalam penelitian ini dirumuskan dalam bentuk pernyataan penelitian yaitu Seberapa besar pengaruh pengembangan karier terhadap kepuasan kerja penyuluh perikanan.

Tujuan Penelitian

Tujuan penelitian adalah:Untuk mengtahui pengaruh pengembangan karier terhadap kepuasan kerja penyuluh perikanan di kabupaten Bogor

\section{Kerangka Berpikir dan Hipotesis}

Kerangka pikir

Adapun kerangka pemikiran penelitian adalah untuk mengetahui: Pengembangan Karier (X) adalah variabel bebas kedua merupakan skor yang diperoleh dari pengukuran dengan menggunakan angket sebagai variabel bebas Pengembangan karier mempunyai dua dimensi,

Tabel 1. Kisi-kisi Indikator Instrumen

\begin{tabular}{|c|c|c|c|c|c|}
\hline No & Variabel & Dimensi & Indikator & No. Item & $\sum$ Item \\
\hline 1 & $\begin{array}{l}\text { Pengembangan } \\
\text { karier }\end{array}$ & $\begin{array}{l}\text { a. Jenis Pengembangan } \\
\text { Karier } \\
\text { b. Efektivitas }\end{array}$ & $\begin{array}{l}\text { 1. Promosi } \\
\text { 2. Rotasi/mutasi } \\
\text { 3. Kenaikan pangkat } \\
\text { 1. Sikap Kerja } \\
\text { 2. Kesesuaian jabatan }\end{array}$ & $\begin{array}{c}1,2,3,4 \\
5,6,7,8 \\
9,10,11,12,13 \\
14,15 \\
\\
16,17 \\
18,19,20\end{array}$ & $\begin{array}{l}4 \\
4 \\
5 \\
2 \\
\\
2 \\
4\end{array}$ \\
\hline
\end{tabular}


(1) dimensi pertama yaitu jenis pengembangan karier dan dapat diukur dengan Promosi, Rotasi/mutasi yaitu seberapa besar peluangnya untuk dapat menduduki posisi tertentu seperti koordinator, penyuluh pbidang merikanan maupun posisi lainnya, mutasi yaitu bagaimana perputaran atau perpindahan dari suatu jabatan atau tempat kerja yang satu ke tempat kerja yang lainnya dan kenaikan pangkat yaitu berapa lama waktu yang dibutuhkan untuk dapat naik pangkat satu tingkat lebih tinggi dari pangkat sebelumnya, sedangkan dimensi kedua adalah efektivitas dan dapat diukur dengan sikap kerja dan kesesuaian jabatan. (2) sedangkan dimensi kedua adalah efektivitas dan dapat diukur dengan sikap kerja, yaitu bagaimana penyuluh melakukan pekerjaan sesuai dengan tugas pokok dan fungsinya dalam rangka mencapai tujuan oraganisasi dan kesesuaian jabatan yaitu jenjang jabatan yang dimiliki apakah sudah sesuai dengan atuan-aturan yang ada.

Pengembangan karier merupakan faktor yang mendukung efektivitas individu dan organisasi dalam mencapai tujuan yang mengarah kepada pencapaian kebutuhan, memberi kepuasan kerja pegawai ataupun mengurangi ketidak seimbangan (sutanto dalam Edy sutrisno,2012;159) Dengan demikian diduga pengembangan karier secara nyata berpengaruh terhadap kepuasan kerja penyuluh perikananMenurut Andrew J. Fubrin yang dikutip dari Mangkunegara (2004) pangembangan karir adalah aktivitas kepegawaian yang membantu pegawai pegawai merencanakan karier masa depan mereka di perusahaan agar perusahaan dan pegawai yang bersangkutan dapat mengembangkan diri secara maksimum.
Hipotesis

Dari uraian di atas maka dapat dikemukakan hipotesis sebagai berikut; Diduga terdapat pengaruh pengembangan karier terhadap kepuasan kerja penyuluh perikanan.

\section{Metode Penelitian}

Definisi Variabel dan Operasional Variabel

Menurut Sugiyono (2010:32) variabel penelitian adalah suatu atribut atau sifat atau nilai dari orang, objek atau kegiatan yang mempunyai variasi tertentu yang diterapkan oleh peneliti untuk dipelajari dan ditarikkesimpulannya. Dari judul penelitian didapatkan dua variabel, yaitu; a. Variabel Bebas (Independen/Exogenous), adalah variabel yang mempengaruhi variabel lainnya, dinyatakan dalam " $\mathrm{X}$ ", dimana pengembangan karier adalah sebagai X1, b. Variabel Terikat Dependen/Endogenous). Variabel terikat atau tidak bebas adalah variabel yang dipengaruhi oleh variabel lainnya, dalam penelitian ini adalah kinerja karyawan dan dinyatakan dalam "Y".

Tempat dan Waktu Penelitian

Penelitian tentang pengaruh pengembangan karier terhadap kepuasan kerja penyuluh dilaksanakan di Badan Ketahanan Pangan Pelaksana Penyuluhan Perikanan dan Kehutanann Kabupaten bogor. penelitian dilaksanakan selama empat bulan yaitu dari Bulan Agustus sampai dengan Bulan November 2013. Badan Ketahanan Pangan Pelaksana Penyuluhan Perikanan dan Kehutanan adalah salah satu lembaga teknis daerah di kabupaten bogor yang mengelola pegawai fungsional khususnya penyuluh pertanian, perikanan, perkebunan, kehutanan.

Populasi dan Sampel

Menurut Sugiyono (2010:80) populasi dalah wilayah generalisasi yangterdiri atas objek atau subjek yang mempunyai kualitas dan 
karakteristik tertentu yang ditetapkan oleh peneliti untuk dipelajari dan kemudian ditarik kesimpulannya. Sampel adalah bagian dari jumlah dan karakteristik yang dimiliki oleh populasi tersebut. Pada penelitian ini jumlah popula Populasi penelitian ini adalah seluruh penyuluh yang bekerja pada Badan Pelaksana Penyuluhan Pertanian Perikanan dan Kehutanan baik sebagai pegawai tetap maupun pegawai kontrak yang berjumlah 268 orang terdiri dari pegawai tetap berjumlah 252 orang dan pegawai kontrak berjumlah 16 orang, dengan memperhatikan populasi yang homogen maka teknik sampling yang digunkanan adalah simple random sampling (sampel acak sederhana) yang merupakan bagian dari propability sampling. Dari hasil penghitungan diperoleh data tabel dalam penelitian ini ditetapkan 51 orang jumlah sampelnya sebagai berikut : a. Pegawai tetap 35 Orang, b. Pegawai kontrak 16 orang.

\section{Hasil Penelitian}

Gambaran Umum Obyek Badan Pelaksana Penyuluhan Pertanian Perikanan dan Kehutanan dibentuk dengan Peraturan Daerah kabupaten Bogor Nomor 15 Tahun 2008, tentang Pembentukan Badan Pelaksana Penyuluhan Pertanian Perikanan dan Kehutanan. Lembaga ini merupakan wadah pengkoordinasian tenaga fungsional penyuluh pertanian dan kehutanan, peternakan dan perikanan, yang mana sebelumnya tenaga fungsional tersebut berada di Dinas teknis, yaitu penyuluih pertanian dan kehutanan di Dinas Pertanian dan Kehutanan, sedangkan penyuluh peternakan dan perikanan berada di Dinas Peternakan dan Perikanan.

Badan Pelaksana Penyuluhan Pertanian, Perikanan dan Kehutanan merupakan unsur pelaksana pemerintah daerah yang dipimpin oleh seorang Kepala Badan yang berada dibawah dan bertanggungjawab kepada Bupati melalui Sekretaris Daerah. Mempunyai tugas membantu Bupati dalam melaksanakan urusan Pemerintahan Daerah di bidang penyelenggaraan penyuluhan pertanian, perikanan dan kehutanan, selain itu Badan Pelaksana Penyuluhan Pertanian Perikanan dan Kehutanan mempunyai fungsi antara, lain : penyusun kebijakan dan program penyuluhan daerah yang sejalan dengan kebijakan dan program naswional. pegawai badan ketahanan pangan pelaksana penyuluhan perikanan dan kehutanann adalah 282 orang terdiri dari 14 org pegawai struktural 268 pegawai fungsional, pegawai fungsional terdiri dari 178 orang penyuluh pertanian, 35 orang penyuluh perikanan, 14 orang penyuluh peternakan, penyuluh kehutnan 25 orang, 16 orang thl. obyek yang akan diteliti adalah sebanak 209 pegawai fungsional dan non

Tabel 2. Karakteristik Penyuluh Berdasarkan Pangkat/Golongan

\begin{tabular}{|c|l|c|c|}
\hline No & \multicolumn{1}{|c|}{ Pangkat/Gol } & Jumlah & Prosentase \\
\hline 1 & Pengatur T.I/ II/d & 1 & 1.96 \\
\hline 2 & Penata Muda/ III/a & 2 & 3.92 \\
\hline 3 & Penata Muda Tk.I/ III/b & 9 & 17.65 \\
\hline 4 & Penata/III/c & 5 & 15.69 \\
\hline 5 & Penata Tk.I/III/d & 10 & 9.80 \\
\hline 6 & Pembina/IV/a & 16 & 19.61 \\
\hline 7 & Honorer (THL-TB) & 51 & 31.37 \\
\hline & Jumlah & & 100.00 \\
\hline
\end{tabular}


fungsional. analisa deskriptif data penelitian

Karakteristik Pegawai

Untuk melengkapi ataupun memperkuat analisa tentang pengaruh dari variabel-variabel yang diteliti, maka disajikan berbagai karakteristik pegawai, sebagai berikut :

a. karakteristik pegawai berdasarkan pangkat/golongan

Dari keseluruhan jumlah responden yang diteliti diperoleh hasil karakteristik responden menurut golongan yakni responden yang terbanyak mempunyai golongan 2 yaitu 1 orang $(1,96 \%)$ diikuti oleh responden golongan 3 yakni 25 orang $(47,06 \%)$, dan responden golongan 4 sebanyak 10 orang $(19,61 \%)$. Sedangkan responden tenaga kontrak (THL-TB) adalah 16 orang.(31,37\%). Uraian mengenai hal ini disajikan pada Tabel 2.

Berdasarkan Tabel diatas dapat dilihat bahwa responden pada level Honorer sebanyak 16 orang atau $31,37 \%$, golongan IV/a sebanyak 10 orang atau $19,61 \%$, golongan III/b sebanyak 9 orang atau $17,65 \%$, golongan III/c sebanyak 8 orang atau $15,69 \%$, golongan III/d sebanyak 5 orang atau 9,8\%, golongan III/a sebanyak 2 orang atau 3,92\% dan penyuluh golongan II/d sebanyak 1 orang atau1,96\%.

Dari data diatas dapat disimpulkan bahwa dari sisi golongan/pangkat penyuluh secara akumulatif didominasi oleh penyuluh golongan III yaitu sebanyak 25 orang atau $47,06 \%$, dengan demikian para penyuluh masih dimungkinkan untuk meningkatka $\mathrm{n}$ kariernya ke jenjang lebih tinggi. sesuai pernyataan(Robbins, 2003), bahwa kepuasan kerja, kondisi pasar kerja, tersedianya kesempatan kerja alternatif, dan lama masa kerja dalam organisasi, dan Semenjak iberlakukannya pengembangan karir terbatas dan tidak terbatas bagi satuan-satuan kerja tertentu

b. Karakteristik Pegawai Berdasarkan Tingkat Pendidikan

Dari jumlah responden yang diteliti diperoleh karakteristik responden dilihat dari tingkat pendidikan yakni responden terbanyak berlatar pendidikan S-1 sebesar 22 orang (43.14\%) diikuti oleh responden yang berpendidikan Diploma III 14 orang $(27,45 \%)$, SLTA/sederajat yakni 13 orang $(25,49 \%)$, dan terakhir ialah responden yang berlatar pendidikan Diploma IV sebanyak 2 orang atau $3.92 \%$. Rincian hal ini disajikan pada tabel 3.

Dari tabel diatas bahwa sebagian besar tingkat pendidikan penyuluh adalah sarjana 22 orang atau 43,14\% dan Diploma IV sebanyak 2 orang $(3,92 \%)$, yaitu penyuluh pertanian ahli, yang pangkat puncaknya dapat mencapai IV/c, dengan demikian kemungkinan penyuluh masih potensial untuk mengembangkan kariernya.

Tabel 3. Karakteristik Pegawai Berdasarkan Pendidikan

\begin{tabular}{|c|l|c|c|}
\hline No & Uraian & Jumlah & Prosentase \\
\hline 1 & SLTA & 13 & 25.49 \\
\hline 2 & Diploma III & 14 & 27.45 \\
\hline 3 & Diploma IV & 2 & 3.92 \\
\hline 4 & Sarjana (S1) & 22 & 43.14 \\
\hline & Jumlah & 51 & 100.00 \\
\hline
\end{tabular}


Tabel 4 Karakteristik Pegawai Berdasarkan Masa Kerja

\begin{tabular}{|r|c|c|c|}
\hline No & Masa Kerja & Jumlah & Prosentase \\
\hline 1 & $<5$ Tahun & 16 & 31.37 \\
\hline 2 & 06-10 Tahun & 0 & 0 \\
\hline 3 & $11-15$ Tahun & 4 & 7.84 \\
\hline 4 & $16-20$ Tahun & 7 & 13.73 \\
\hline 5 & $21-25$ Tahun & 17 & 33.33 \\
\hline 6 & 26-30 Tahun & 5 & 9.8 \\
\hline 7 & $>30$ Tahun & 2 & 3.892 \\
\hline & Jumlah & 51 & 100 \\
\hline
\end{tabular}

c. Karakteristik Pegawai Berdasarkan Masa Kerja

Dari jumlah responden yang diteliti diperoleh hasil karakteristik responden menurut masa kerja yakni responden yang terbanyak dengan masa kerja antara 21 sampai dengan 25 tahun sebesar 17 orang $(33,33 \%)$ diikuti oleh responden dengan masa kerja5 tahun yakni 16 orang $(31.37 \%)$, responden dengan masa kerja antara 16 sampai dengan 20 tahun sebesar 7 orang $(13,33 \%)$ dan responden dengan masa kerja 26sampai dengan 30 tahun sebanyak 5 orang (9,8\%). Masakerja 11 tahun sampai dengan 15 tahun sebanyak 4 orang $(7,84 \%)$. Selanjutnya diatas 30 tahun sebanyak 2 orang $(3,92 \%)$ Uraian tentang hal ini disajikan pada tabel 5. berikut : d. Karakteristik Pegawai dasarkanMasa kerja Dari jumlah responden yang diteliti diperoleh hasil karakteristik responden menurut usia yakni responden yang terbanyak berusia antara46 sampai dengan 50 tahun sebesar 16 orang $(31,37 \%)$ diikuti oleh responden berusia di bawah 30 tahun sampai 35 tahun yakni 10 orang $(19,61 \%)$, responden berusia antara 56 sampai dengan 60 tahun sebanyak 7 orang $(13,73 \%)$ dan responden berusia antara di atas 30 tahun sebanyak 6 orang $(11,76 \%)$, serta usia 51 samapa 55 tahun sebanyak 6 orang atau 76\%). Usia 41 sampai dxengan 45 tahun sebanyak 5 orang sebesar (9,80\%), Dan usia 36-40 sebanyak 1 orang (sebesar(11, 1,96\%) Uraian tentang hal ini disajikan pada tabel 5 .

Tabel 5. Karakteristik Pegawai Berdasarkan Usia

\begin{tabular}{|c|c|c|c|c|}
\hline \multirow{2}{*}{ No } & \multicolumn{2}{|c|}{ Usia } & Jumlah & Prosentase \\
\hline 1 & $>30$ & Tahun & 6 & 11.76 \\
\hline 2 & $30-35$ & Tahun & 10 & 19.61 \\
\hline 3 & $36-40$ & Tahun & 1 & 1.96 \\
\hline 4 & $41-45$ & Tahun & 5 & 9.8 \\
\hline 5 & $46-50$ & Tahun & 16 & 31.37 \\
\hline 6 & $51-55$ & Tahun & 6 & 11.76 \\
\hline 7 & $56-60$ & Tahun & 7 & 13.73 \\
\hline & & & & \\
\hline & jumlah & Tahun & $\mathbf{5 1}$ & $\mathbf{1 0 0}$ \\
\hline
\end{tabular}


Tabel. 6 Distribusi Skor Pengembangan Karier

\begin{tabular}{|c|c|c|c|c|}
\hline No & Interval kelas & Frekwensi absolut & Frekwensi Relatif(\%) & Frekwensi Kumulatif(\%) \\
\hline 1 & $66-68$ & 5 & 9.8 & 9.8 \\
\hline 2 & $69-71$ & 5 & 9.8 & 19.61 \\
\hline 3 & $72-74$ & 4 & 7.84 & 27.45 \\
\hline 4 & $75-77$ & 20 & 39.22 & 66.67 \\
\hline 5 & $78-80$ & 9 & 17.65 & 84.31 \\
\hline 6 & $81-83$ & 6 & 11.76 & 96.08 \\
\hline 7 & $84-86$ & 2 & 3.92 & 100 \\
\hline & & & & \\
\hline & jumlah & $\mathbf{5 1}$ & $\mathbf{1 0 0}$ & \\
\hline
\end{tabular}

Diskripsi Data Setiap Variabel

Pengembangan karier

Data Pengembangan Karier dari kuesioner ini menyebar dari skor terendah 66 dan tertinggi 86. Rentangan skor yang muncul adalah sebesar 18 dari 66 sampai 86. Analisis data menghasilkan rata-rata sebesar 75,84 dengan standar deviasi 3,866 dimana jumlah responden yang diukur sebanyak 51. Banyak kelas yang ditetapkan sebanyak 7 kelas dengan panjang kelas 3. Selanjutnya distribusi frekuensi skor Pengembangan Karier menurut aturan Sturges disajikan pada tabel berikut:

Dari tabel tersebut dapat dilihat bahwa sebanyak 20 responden $(39,22 \%)$ berada pada kelompok rata-rata, 14 responden $(27,24 \%)$ berada pada kelompok di bawah rata-rata dan 17 responden $(33,33 \%)$ berada di atas rata-rata. Dari data tersebut terlihat bahwa Pengembangan Karier para pegawai di Badan Pelaksana Penyuluhan Pertanian Perikanan dan Kehutanan sudah cukup baik meskipun harus ditingkatkan, hal ini terlihat dari jawaban responden tentang Pengembangan Karier dimana 20 responden atau $72,55 \%$ jawabannya berada pada skor rata-rata dan di atas rata-rata. Distribusi skor variabel Pengembangan Karier. bahwa skor data yang diperoleh cenderung menyebar. Skor tengah cenderung lebih tinggi dari skor atas dan bawah. Gambaran ini terlihat dari histogramnya yang cenderung memiliki angka tengah yang lebih tinggi. Hal ini berarti bahwa data skor Variabel Pengembangan Karier cenderung mempunyai distribusi normal.seperti halnya disampaikan Breitweg, J., et al Dessler (1997) berpendapat bahwa dengan adanya perencanaan dan pengembangan karir, keuntungan yang jelas bagi pegawai adalah kepuasan, pengembangan pribadi, dan kehidupan kerja yang berkualitas. Beberapa manfaat strategik yang mungkin diperoleh dari pelatihan dan pengembangan mencakup kepuasan karyawan, meningkatnya semangat, tingkat retensi yang lebih tinggi.

Kepuasan Kerja

Data Kepuasan Kerja yang berasal dari kuesioner ini menyebar dari skor terendah 65 dan tertinggi 84. Dengan demikian, rentangan skor yang muncul adalah sebesar 19 dari 65 sampai 84. Selanjutnya dilakukan analisis dan hasilnya diperoleh rata-rata sebesar 73,71 dengan tingkat standar deviasi sebesar 3,870 dimana jumlah responden yang diukur sebanyak 51. Banyak kelas yang ditetapkan dalam penelitian ini terdiri dari 7 kelas dengan panjang kelas 3. Selanjutnya distribusi frekuensi skor Kepuasan Kerja menurut aturan Sturges disajikan pada tabel 6.

Dari tabel tersebut dapat dilihat bahwa sebanyak 17 responden $(33,33 \%)$ berada pada kelompok rata-rata, 13 responden $(25,28 \%)$ berada pada kelompok di bawah rata-rata dan 21 
Tabel 7. Distribusi Skor Kepuasan Kerja

\begin{tabular}{|c|c|c|c|c|}
\hline No & $\begin{array}{c}\text { Interval } \\
\text { kelas }\end{array}$ & $\begin{array}{c}\text { Frekwensi } \\
\text { Absolut }\end{array}$ & $\begin{array}{c}\text { Frekwensi Relatif } \\
(\mathbf{\%})\end{array}$ & $\begin{array}{c}\text { Frekwensi kumulatif } \\
(\mathbf{\%})\end{array}$ \\
\hline 1 & $65-67$ & 4 & 7.84 & 7.84 \\
\hline 2 & $68-70$ & 4 & 7.84 & 15.69 \\
\hline 3 & $71-73$ & 5 & 9.8 & 25.49 \\
\hline 4 & $74-76$ & 17 & 33.33. & 58.82 \\
\hline 5 & $77-79$ & 7 & 13.73 & 72.55 \\
\hline 6 & $80-82$ & 8 & 15.69 & 88.24 \\
\hline 7 & $83-85$ & 6 & 11.76 & 100 \\
\hline & jumlah & $\mathbf{5 1}$ & $\mathbf{1 0 0}$ & \\
\hline
\end{tabular}

responden $(41,18 \%)$ berada di atas rata-rata. Dari data tersebut terlihat bahwa Kepuasan Kerja para pegawai di Badan Pelaksana Penyuluhan Pertanian Perikanan dan Kehutanan sudah cukup baik meskipun harus ditingkatkan, hal ini terlihat dari jawaban responden tentang Kepuasan Kerja dimana 38 responden atau 74,34\% jawabannya berada pada skor rata-rata dan di atas rata-rata. Gambaran lebih jelas mengenai distribusi skor data variabel Kepuasan Kerja, skor data yang diperoleh cenderung menyebar. Skor tengah cenderung lebih tinggi dari skor atas dan bawah. Gambaran ini terlihat dari histogramnya yang cenderung memiliki angka tengah yang lebih tinggi. Hal ini berarti skor Variabel Kepuasan Kerja cenderung mempunyai distribusi normal.

\section{Pembahasan}

Pengujian Korelasi

Guna mengetahui secara detail hubungan antara variabel Pengembangan Karier dengan Kepuasan Kerja maka perlu dilakukan pengujian dengan menggunakan model pengujian korelasi. Hasil pengujian korelasi adalah sebagai berikut :

Hasil pengolahan data tersebut menjelaskan bahwa nilai korelasi antara Pengembangan Karier dengan Kepuasan Kerja pada Badan Pelaksana Penyuluhan Pertanian Perikanan dan Kehutanan memperlihatkan hasil sebesar 0.876. Dengan demikian menunjukkan adanya hubungan positif sangat kuat antar variabel. Artinya bila variabel Pengembangan Karier ditingkatkan maka akan meningkatkan variabel Kepuasan Kerja pada Badan Pelaksana Penyuluhan Pertanian Perikanan dan Kehutanan.Selanjutnya dilakukan uji regresi guna menguji hipotesis terhadap kedua variabel yang diteliti, dan setelah dilakukan pengolahan diperoleh hasil pengujian sebagai berikut :

$\mathrm{Y}=\mathrm{a}+\mathrm{b}_{1} \mathrm{X}_{1}$

dimana

$\mathrm{Y}=4,995+0,624 \mathrm{X}_{1}$

Hasil pengolahan data dengan uji regresi di atas dapat dijelaskan sebagai berikut :

1. Hasil constanta menunjukkan nilai sebesar 4,995. Dengan demikian, variabel Kepuasan Kerja pada Badan Pelaksana Penyuluhan Pertanian Perikanan dan Kehutanan murni tanpa adanya pengaruh oleh Pengembangan Karier sebesar 4,995.

2. Nilai regresi $b_{1}$ (Pengembangan Karier) didapat sebesar 0,624. Dengan demikian, terdapat kontribusi oleh Variabel Pengembangan Karier, yang berarti bila Badan Pelaksana Penyuluhan Pertanian Perikanan dan Kehutanan meningkatkan Kepuasan Kerja 1 skor maka berpengaruh terhadap peningkatan Kepuasan Kerja pada Badan Pelaksana Penyuluhan Pertanian

Tabel 8. Hasil Pengujian Korelasi

\begin{tabular}{|c|c|c|}
\hline \multirow[t]{2}{*}{ Volume 9 Nomor } & Uraian & Kepuasan kerja \\
\hline & Pengembangan karir & 0,876 \\
\hline
\end{tabular}


Tabel 9. Hasil Uji Regresi

\begin{tabular}{|l|c|c|c|c|c|}
\hline & \multicolumn{2}{|c|}{$\begin{array}{c}\text { Unstandardized } \\
\text { Coefficients }\end{array}$} & $\begin{array}{c}\text { Unstandardized } \\
\text { Coefficients } \\
\text { Beta }\end{array}$ & t & \multirow{2}{*}{ Sig } \\
\cline { 2 - 5 } & B & Std Error & . & 1,588 & 0,114 \\
\hline Konstanta & 4,995 & 3,146 & & 8,407 & 0,000 \\
\hline Pengembangan Karier & 0,624 & 0,074 & 0,563 & \\
\hline
\end{tabular}

Perikanan dan Kehutanan sebesar 0,624 skor.

Uji Hipotesis Individu (Uji t) Dengan kaidah :

$t_{\text {hitung }}>t_{\text {tabel }}\left(\mathrm{H}_{0}\right)$ ditolak dan $\left(\mathrm{H}_{\mathrm{a}}\right)$ diterima, maka ada hubungan antara $\mathrm{X}$ terhadap $\mathrm{Y}$.

$t_{\text {hitung }}<t_{\text {tabel }}\left(\mathrm{H}_{0}\right)$ diterima dan $\left(\mathrm{H}_{\mathrm{a}}\right)$ ditolak, maka tidak ada hubungan antara $\mathrm{X}$ terhadap Y. $\alpha=0,05$ atau $5 \%$

Variabel Pengembangan Karier

Hasil pengolahan data menunjukkan nilai $\mathrm{t}_{\text {hitung }}$ sebesar 8,407 dimana $\mathrm{t}_{\text {tabel }}$ sebesar 1,588. Dengan demikian $\mathrm{t}_{\text {hitung }} 8,407>\mathrm{t}_{\text {tabel }} 1,588$ maka $\left(\mathrm{H}_{0}\right)$ ditolak dan $\left(\mathrm{H}_{\mathrm{a}}\right)$ diterima artinya ada hubungan antara variabel Pengembangan Karier (X) dengan Kepuasan Kerja (Y) pada Badan Pelaksana Penyuluhan Pertanian Perikanan dan Kehutanan.Sedangkan probabilitas hasil sebesar 0,000 atau $0 \%$ dimana nilai $\alpha=0,05$ atau $5 \%$ dengan demikian probabilitas di bawah nilai alpha, berarti variabel Pengembangan Karier (X) signifikan terhadap Kepuasan Kerja pada Badan Pelaksana Penyuluhan Pertanian Perikanan dan Kehutanan.

Hasil uji hipotesa tersssebutbahwa: 1). Terdapat pengaruh langsung negatif dansignifikan antara pengembangan karir (X1) dengan kepuasan kerja (Y1) dengan koefisien sebesar -0,23 dan p-value sebesar 0,006. Maknanya adalah pengembangan karir yang baik terbukti mampu mengurangi minat karyawan untuk melakukan pekerjaan yang dapat memberikan kepuasan kerja bagi pegawai.
Temuan penelitian ini mendukung hasil penelitian yang dilakukan Lu dan Seock (2008);

Martin (2012), dan Radea (2010) bahwa pengembangan karir memiliki pengaruh ignifikan terhadap kepuasan kerja karyawan atau pegawai. Demikian pula penelitian yang dilakukan Ming (2008) pada 375 karyawan di Malaysia menyatakan bahwa kesempatan pengembangan karir berpengaruh negatif signifikan terhadap 1).keinginan keluar (pension dini) dari perusahaan, 2).Maknanya adalah pemberian motivasi berperan penting dalam mempengaruhi karyawan untuk melakukan pengembangan karir.. Semakin baik motivasi kerja yang diberikan, maka kepuasan kerja akan semakin meningkat.. Hasil penelitian ini sesuai dengan penelitian Trisiyanie (2010). Demikian pula penelitian yang dilakukan Jung (2008) pada industry perhotelan bahwa motivasi berpengaruh kepuasan kerja . seperti halnya juga penelitian oleh Dipang, Ludfia. (2013) menyatakan tentang Jenjang Karir Jenjang karir merupakan program yang dirasa paling mempengaruhi peningkatan kinerja karyawan. Menurut Stephen P. RobbinsTimothy A. Judge (2011), Perilaku organisasi (organizational behavior) adalah bidang studi yang menyelidiki pengaruh yang dimiliki oleh individu, kelompok dan struktur organisasi.

\section{Kesimpulan dan Saran}

Kesimpulan

Berdasarkan penelitian yang dilakukan mengenai Pengembangan Karier terhadap Kepuasan Kerja pada Badan Ketahanan Pangan Pelaksana Penyuluhan Pertanian Perikanan dan 
Kehutanan dan hasil pengolahan data terhadap variabel bebas Pengembangan Karier (X) serta variabel terikat Kepuasan Kerja (Y) pada Badan Pelaksana Penyuluhan Pertanian Perikanan dan Kehutanan dapat diambil beberapa kesimpulan sebagai berikut :

1. Hasil uji $\mathrm{t}$ variabel Pengembangan Karier (X) terhadap Kepuasan Kerja (Y) pada Badan Pelaksana Penyuluhan Pertanian Perikanan dan Kehutanan menunjukkan bahwa nilai thitung sebesar 8,407 dan $t_{\text {tabel }}$ sebesar 1,588 pada level significants 0,05 dan probabilitas 0,000 . Hal ini berarti $t_{\text {hitung }}=$ $8,407>\mathrm{t}_{\text {tabel }}=1,588$ maka $\mathrm{H}_{0}$ ditolak dan $\mathrm{H}_{\mathrm{a}}$ diterima, berarti terdapat pengaruh Pengembangan Karier (X) terhadap Kepuasan Kerja (Y) pada Badan Pelaksana Penyuluhan Pertanian Perikanan dan Kehutanan.

2. Koefisien korelasi Pengembangan Karier (X) secara bersama-sama terhadap Kepuasan Kerja (Y) pada Badan Pelaksana Penyuluhan Pertanian Perikanan dan Kehutanan adalah 0,876 sehingga diperoleh nilai koefisien determinasi sebesar 0,876 atau 87,6\%. Hal ini berarti bahwa faktor-faktor lain di luar yang tidak diteliti namun berpengaruh juga adalah sebesar $12,4 \%$.

Saran

1. Selain itu, untuk lebih meningkatkan Kepuasan Kerja pada Badan Pelaksana Penyuluhan Pertanian Perikanan dan Kehutanan dapat dilakukan melalui pemenuhan pengembangan Karier. Apabila para Pegawai yang bekerja pada Badan Pelaksana Penyuluhan Pertanian Perikanan dan Kehutanan merasakan iklim kerja yang kondusif dan adanya pola Pengembangan Karier yang baik dalam bekerja maka bukan tidak mungkin kepuasan Kerja pun akan meningkat. Selain itu perlu ditekankan prinsip “ enangilah apa yang kamu kerjakan dan bukan kerjakanlah apa yang kamu senangi “.

2. Apabila pengembangan karier yang dirasakan para pegawai terpenuhi dimana kondisinya para pegawai mempunyai motivasi yang tinggi dalam bekerja dan sistem kerja serta sarana dan prasarana kerja yang ada sudah mampu meningkatkan Pengembangan Karier maka tidak mustahil kepuasan kerja akan meningkat. Oleh karena itu, pimpinan Badan ketahanan pangan Pelaksana Penyuluhan Perikanan dan Kehutanann perlu terus memotivasi para pegawai dan menciptakan iklim kerja yang dapat terciptanya Pengembangan Karier untuk meningkatkan kepuasan kerja penyuluh perikanan khususnya.

\section{Daftar Pustaka}

2006, "Metode Penelitian Manajemen Edisi 2",Badan Penerbit Universitas Diponegoro, Semarang

Breitweg, J., Derrick, M., Krakauer, D., Magill, S., Mikunas, D., Musgrave, B., ... \& Zhang, H. (1997). Measurement of the proton structure function F 2 and otot $\gamma *$ $\mathrm{p}$ at low $\mathrm{Q} 2$ and very low $\mathrm{x}$ at HERA. Physics Letters B, 407(3), 432-448.

Dipang, Ludfia. 2013."Pengembangan Sumber Daya Manusia Dalam Peningkatan Kinerja Karyawan Pada PT. Hasjrat Abadi Manado." JURNAL RISET EKONOMI, MANAJEMEN, BISNIS DAN AKUNTANSI 1.3

Dole, Carol and Schroeder, Richard G., 2001, "The Impact of Various Factors onThe Personality, Job Satisfaction and Turnover Intention of ProfesionalAccountants", Managerial Auditing Journal, Vol. 16, No. 4, p. 234 $-245$ 
Handoko T Hani. 2002 . "Paradigma Baru Manajemen Sumberdaya Manusia", Asmara Books Jogyakarta.

Hasibuan Malahayu. 2001.DM. Sumber Daya Manusia, Bumi Aksara Jakarta

Jung. BS. 2008. The impact of career motivation and polychronemployees, aster Thesis icity on job satisfaction and furnover intention among hotel industry, Universitas North Texas.

Luthans, F. 2002. Organizational Behavior. NewYork: Mc Graw Hill

Mariot T.E.Hariandja,,2002, Manajemen umberdaya Manusia, PT.Gramedia, Jakarta

Ming. Fung. 2008. Linking Career Development Practices to Turnover Intention: The Mediator of Perceived Organizational Support. Jurnal business and Public Affair.Volume 2, Issue 1, 2008

Nasution, Wendi Amsuri.2009. Pengaruh kepuasan Kerja Karyawan Terhadap tensi Turnover pada call center Telkomsel di Medan. Jurnal Aplikasi Manajemen.Vol.8, No.2 Halaman 307317

Panggabean, Mutiara., S2002. Manajemen SumberdayaManusia,Ghalia Indonesia, Jkarta

Rivai, Veithzaldan Sagala, Jauvani, 2009. Manajemen Sumber Daya Manusia untuk Perusahaan: dari Teori ke Praktek. Jakarta: Rajawali Press

Riyanto, Makmun. 2008. Faktor-faktor yang mempengaruhi Keinginan Karyawab Ber pindah Kerja. Jurnal Ragam Vol.8, No.3. Halaman 26-36

Robbins, Stephen P., and Timothy A. Judge. "Perilaku organisasi." Edisi Bahasa Indonesia. Jakarta. PT. Indeks Kelompok Gramedia (2006

Robinson \& Aprilia, Nila 2005.Pengaruh komitmen Organisasi. Kepuasan Kerja, dan Keperilakuan Etis terhadap Keinginan Berpindah pada Profesional Bidang teknologi Informasi. Jurnal Bisnis \& Manajemen. Vol.5, No.1 Hal. 23-24

Sugiyono.2010,Metoda Penelitian Bisnis, CV lfabeta, Bandung
Sunyoto Danang, 2012, Manajemen Sumberdaya Manusia, PT.Buku Seru,Jakarta

Testa, Mark R., 1999, "Satisfaction with organizational Vision, Job atisfactionand Service Effort: An Empirical Investigation", Leadership and Organization Development Journal, Vol. 20, No. 3 